\title{
Effects of animal versus vegetal rennet on milk coagulation traits in Mediterranean buffalo bulk milk
}

\author{
C. L. Manuelian, ${ }^{1 *} \odot$ C. Boselli, ${ }^{2} \odot$ V. Vigolo, ${ }^{1} \odot$ G. Giangolini, ${ }^{2} \odot$ and M. De Marchi ${ }^{1} \odot$ \\ ${ }^{1}$ Department of Agronomy, Food, Natural Resources, Animals and Environment (DAFNAE), University of Padova, 35020 Legnaro (PD), Italy \\ ${ }^{2}$ Istituto Zooprofilattico Sperimentale del Lazio e della Toscana "M. Aleandri"-National Reference Centre for Ovine and Caprine Milk \\ and Dairy Products Quality (C.Re.L.D.O.C.), 00178 Rome, Italy
}

\section{ABSTRACT}

Given consumer interest in Mozzarella di latte di Bufala and other cheeses, and the growing interest of the cheese industry in offering products adequate for lactovegetarian consumers, this study aimed to compare clotting capacity of vegetal and animal rennet in buffalo milk. Milk coagulation properties of 1,261 buffalo bulk milk samples collected during milk quality testing were assessed by lactodynamography using commercial animal ( $75 \%$ chymosin and $25 \%$ bovine pepsin) and vegetal (Cynara cardunculus) rennets. Chemical composition of milk samples was predicted by MilkoScan (Foss Analytics, Hillerød, Denmark) calibrated with specific buffalo standards. Rennet effect (animal versus vegetal) was statistically analyzed with a paired $t$-test. Fat, protein, and lactose contents of milk samples were $7.94 \%, 4.52 \%$, and $4.80 \%$, respectively. A similar variability of milk coagulation properties was observed with both rennets, with the exception of greater variability of curd firmness at 30 min after the addition of vegetal rennet compared with animal rennet (73 and $26 \%$, respectively). On average, when using plant rennet, milk started to coagulate and reached the $20-\mathrm{mm}$ coagulum $12 \pm 0.22 \mathrm{~min}$ and $1.9 \pm 0.20 \mathrm{~min}$, respectively, later than with animal rennet. Thirty minutes after rennet addition, curds were almost twice as firm in animal as in vegetal rennet (difference of $23.92 \pm 0.66 \mathrm{~mm}$ ). However, curd firmness at 60 min was only $1.21 \pm 0.39 \mathrm{~mm}$ thicker with vegetal than with animal rennet. Moreover, when using animal rennet, $99.52 \%$ of samples started coagulating within the first $30 \mathrm{~min}$ of analysis, whereas only $70.42 \%$ did so when using vegetal rennet. We conclude that vegetal rennet has the capacity to coagulate buffalo milk, achieving a similar curd firmness to that of animal rennet at $60 \mathrm{~min}$. Further studies are needed to evaluate the sensory characteristics and consumer

Received July 4, 2019.

Accepted February 11, 2020.

*Corresponding author: carmenloreto.manuelianfuste@unipd.it acceptability of Mozzarella di latte di Bufala processed with vegetal rennet.

Key words: cheese, Mozzarella, plant extract, renneting, vegetarian

\section{INTRODUCTION}

Buffalo (Bubalus bubalis) milk is the second most produced milk after bovine milk, representing $15 \%$ of worldwide production in 2017 (FAOSTAT, 2019). Buffalo milk production in Italy has increased considerably in the last $50 \mathrm{yr}$ and represents approximately $95 \%$ of the total buffalo milk produced in the European Union (FAOSTAT, 2019). In Italy, buffalo milk is mainly made into Mozzarella di Bufala Campana PDO (protected designation of origin), although the manufacturing of other cheese types and dairy products has been investigated (Borghese, 2005; Addeo et al., 2007). The steady increase of buffalo milk production could be ascribed to the higher price of buffalo milk (about $1.50 € / \mathrm{L}$ in Italy; CLAL, 2019b) compared with cow milk (about $0.37 € / L$ in Italy; CLAL, 2019a) and to the worldwide increase of consumption of Mozzarella (Borghese, 2013).

Milk coagulation is an important step in cheese manufacturing; thus, the renneting properties of milk are crucial aspects informing milk processability for the cheesemaking process. The most relevant milk coagulation properties (MCP) are rennet coagulation time (RCT), curd firming time $\left(\mathbf{k}_{\mathbf{2 0}}\right)$, and curd firmness 30 min after rennet addition to milk ( $\mathbf{a}_{\mathbf{3 0}}$; McMahon and Brown, 1982); these traits are commonly assessed through lactodynamography. An extended curd firmness (60 min after rennet addition to milk, $\mathbf{a}_{60}$ ) has also been determined in milk samples when using vegetal rennet (Liburdi et al., 2019). Mozzarella di Bufala Campana PDO is produced with animal rennet from the abomasum of calves (Ministero delle Politiche Agricole e Forestali, 2003), containing chymosin and pepsin that coagulate the milk. However, alternatives to animal rennet in cheese production have been stud- 
ied, such as enzymes of microbial origin, recombinant proteases synthesized by genetically modified microorganisms, and plant proteases (Jacob et al., 2011). Among plants, cardosin proteases from Cynara spp. are the most used for cheese manufacturing (Roseiro et al., 2003). The dairy industry's growing interest in using vegetal coagulants for cheese production is due to the global increase in cheese demand and, at the same time, the decreasing supply of calf rennet (Jacob et al., 2011; Bathmanathan et al., 2019), increasing numbers of lactovegetarian consumers, religious considerations (kosher and halal diets), and negative consumer perceptions of the use of genetically modified microorganisms (Roseiro et al., 2003).

Although plant rennet is used for the elaboration of some traditional cheeses in Mediterranean countries, Southern Europe, and West Africa, its use is very limited at industry level due to the high bitterness and lower cheese yield obtained compared with calf rennet (Ben Amira et al., 2017a). Nevertheless, the increasing production of buffalo milk could make room for the development of new and distinguishable products. To our knowledge, there is currently no Mozzarella-type cheese on the market made from buffalo milk with vegetal rennet, and scarce information exists regarding the capability of vegetal rennet to coagulate buffalo milk. Thus, the aim of this study was to investigate the clotting properties of buffalo bulk milk using animal or vegetal rennet.

\section{MATERIALS AND METHODS}

\section{Sample Collection and Reference Analysis}

From January to August 2018, a total of 1,302 buffalo bulk milk samples from herds located in Central Italy (Lazio region) were collected after morning milking (representative of morning and previous evening milkings) during routine sampling for a milk quality payment program. Lazio and Campania are the 2 main Italian regions that produce buffalo milk intended for Mozzarella di Bufala PDO elaboration (Ministero delle Politiche Agricole e Forestali, 2003). In Italy, buffalo are reared in intensive conditions, with dairy buffaloes kept loose in paddocks close to the milking room and artificially inseminated preferably from February to March (Borghese, 2013). Animals are usually fed high-energy, high-protein total mixed rations based on maize silage, concentrate, hay, straw, and sometimes by-products (Borghese, 2013).

Samples were transported refrigerated $\left(4^{\circ} \mathrm{C}\right)$ within 24 to $36 \mathrm{~h}$ from collection to the Experimental Zooprophylactic Institute of Lazio and Tuscany "Mariano Aleandri" (Rome, Italy), the national reference labora- tory for dairy product quality in Central Italy. Milk samples were analyzed for chemical composition, citric acid levels, and SCC using standard methods. Briefly, a MilkoScan FT6000 (Foss Analytics, Hillerød, Denmark) calibrated with appropriate buffalo standards was used to predict fat, protein, casein, and lactose percentages, and a Fossomatic FC (Foss Analytics) was used to determine SCC. The SCC $\times 1,000$ was logarithmically $\left(\log _{10}\right)$ transformed to normalize distribution (Ali and Shook, 1980). The $\mathrm{pH}$ was measured by a potentiometric $\mathrm{pH}$ meter (Mettler Delta 345; Mettler Toledo SpA, Novate Milanese, Italy).

Milk coagulation properties of each sample were determined via Formagraph (Foss Analytics) using animal or vegetal rennet. For MCP determination with animal rennet, milk samples $(10 \mathrm{~mL})$ were heated to $35^{\circ} \mathrm{C}$, and $200 \mu \mathrm{L}$ of commercial calf rennet (Caglificio Clerici spa-Sacco srl, Cadorago, Italy; $75 \%$ chymosin and $25 \%$ bovine pepsin; 175 international milk clotting units/ $\mathrm{mL}$; strength 1:15.000 in Italian commercial units) diluted to $1 \%$ (wt/wt) in distilled water was added to the milk sample. For MCP determination with vegetal rennet, the same procedure was followed, adding to each milk sample $200 \mu \mathrm{L}$ of commercial Galium vegetal rennet (Cynara cardunculus, batch CV60118, Laboratorio Prodor, Bobbio, Italy; 98\% cardosin; strength 1:6.000 in Italian commercial units) diluted to $2.5 \%$ (wt/wt) in distilled water. The analysis was begun simultaneously with both rennets for each milk sample (2 aliquots of the same milk sample were used, 1 for each rennet), and measurement ended 60 min after rennet addition.

\section{Statistical Analysis}

Before statistical analysis, the data set was edited as follows. For milk composition traits (i.e., levels of fat, protein, casein, lactose, citric acid, $\mathrm{pH}$, and $\log _{10}$ SCC), values that deviated more than 3 standard deviations (SD) from the mean of each trait were treated as missing values. For each rennet type, values of RCT and $\mathrm{k}_{20} \leq 0$ or $\geq 60 \mathrm{~min}$, and $\mathrm{a}_{30}$ and $\mathrm{a}_{60}$ that deviated more than $3 \mathrm{SD}$ from the mean were treated as missing values. Then, only traits with data recorded for both rennet types were retained. In addition, records without RCT were deleted. Therefore, the final data set for the statistical analysis consisted of 1,261 records.

Rennet effect was analyzed with a paired $t$-test in SAS version 9.4 (SAS Institute Inc., Cary, NC). The difference for the matched pairs (animal vs. vegetal rennet) for each trait followed a normal probability distribution. Data are presented as means and SD or standard error. Significance was declared at $P<0.05$. Moreover, a new classificatory variable was created based on samples' RCT, stratifying them into 5 classes: 
class $1(\mathrm{RCT}<10 \mathrm{~min})$, class $2(10 \mathrm{~min} \leq \mathrm{RCT}<20$ $\min )$, class $3(20 \mathrm{~min} \leq \mathrm{RCT}<30 \mathrm{~min})$, class $4(30$ $\min \leq \mathrm{RCT}<45 \mathrm{~min})$, and class $5(45 \mathrm{~min} \leq \mathrm{RCT}<$ $60 \mathrm{~min})$.

\section{RESULTS AND DISCUSSION}

\section{Buffalo Bulk Milk Composition}

Chemical composition and $\log _{10}$ SCC of buffalo bulk milk are shown in Table 1. Buffalo milk has greater fat, protein, and casein contents and slightly less lactose than cow milk (Guo, 2010). It is also known that buffalo milk has higher $\mathrm{Ca}, \mathrm{P}$, and $\mathrm{Fe}$, and lower $\mathrm{Na}$ than cow milk (Guo, 2010). These characteristics have important effects on cheesemaking ability that lead to greater cheese yield from buffalo than from cow milk. Fat and protein contents of our samples were similar to the last national statistics available for Italian buffalo milk (A.N.A.S.B., 2019). Several authors have reported fat, protein, casein, lactose, $\mathrm{pH}$, and $\log _{10} \mathrm{SCC}$ contents and ranges in bulk milk of Italian Mediterranean buffalo similar to those obtained in the present study (Di Francia et al., 2003; Liotta et al., 2015; Pasquini et al., 2018). The coefficients of variation (CV) for milk composition ranged from $3 \%$ (lactose) to $8 \%$ (fat), in agreement with the variability reported by Liotta et al. (2015) for bulk milk samples.

\section{Milk Coagulation Properties Using Animal Rennet}

When using animal rennet, 17 out of 1,302 milk samples $(1.3 \%)$ did not start to coagulate within the $60 \mathrm{~min}$ of analysis. Moreover, 30 out of 1,302 samples (2.3\%) did not achieve 20 -mm curd firmness within the $60 \mathrm{~min}$ of analysis. The percentage of samples with RCT or $\mathrm{k}_{20}<60$ min using animal rennet agrees with the outliers reported by Manuelian et al. (2017), who evaluated MCP in individual buffalo milk samples within $30 \mathrm{~min}$ of analysis. However, those authors defined outliers for RCT and $\mathrm{k}_{20}$ as values that deviated more than $3 \mathrm{SD}$ from the mean, among the samples that coagulated in less than 30 min. They classified all samples with an
RCT $>30$ min as non-coagulating, which corresponded to $18 \%$ of their samples.

Table 2 displays the descriptive statistics of MCP for bulk buffalo milk using animal and vegetal rennets. Considering the results obtained with animal rennet, the $\mathrm{CV}$ were $37 \%$ for RCT, $92 \%$ for $\mathrm{k}_{20}, 26 \%$ for $\mathrm{a}_{30}$, and $28 \%$ for $\mathrm{a}_{60}$. The variation within traits observed in the present study contrasted with those reported by Manuelian et al. (2017) from individual buffalo milk samples, in particular for $\mathrm{k}_{20}$. Those authors reported a CV of $45 \%$ for RCT, $39 \%$ for $\mathrm{k}_{20}$, and $38 \%$ for $\mathrm{a}_{30}$. The disagreement between these studies could be due to the type of sample (individual vs. bulk milk), the editing before performing the statistical analysis, and the longer time of analysis in our study (30 vs. $60 \mathrm{~min}$ ). The RCT with animal rennet were similar to those observed by Manuelian et al. (2017) and Ariota et al. (2007) from individual buffalo milk samples, whereas Cecchinato et al. (2012) reported a slightly shorter time (11.62 min) in individual milk and Liotta et al. (2015) a longer time (21.3 min) in bulk buffalo milk. The average $k_{20}$ in our study was longer than those reported in previous studies for individual buffalo milk (3.25 min, Bartocci et al., 2002; 1.73 min, Ariota et al., 2007; 3.17 min, Manuelian et al., 2017) and bulk milk (3.08 min, Liotta et al., 2015). Curd firmness $30 \mathrm{~min}$ after rennet addition was consistent with previous studies in individual buffalo milk samples $(47.49 \mathrm{~mm}$, Bartocci et al., 2002; $46.01 \mathrm{~mm}$, Ariota et al., 2007). Nevertheless, some authors have indicated lower $\mathrm{a}_{30}$ values in bulk (32.69 mm, Liotta et al., 2015) and individual buffalo milk (39.52 mm, Manuelian et al., 2017). We found a very small difference between curd firmness at 30 and 60 min after addition of animal rennet, which supports the idea that $\mathrm{a}_{60}$ is rarely calculated to evaluate MCP when using animal rennet. To our knowledge, this is the first time that $\mathrm{a}_{60}$ has been estimated for buffalo milk. Despite all the studies assessing MCP using lactodynamography, direct comparison of the obtained values should be performed carefully because of the differences in animal rennet solution characteristics, such as the proportion of chymosin to pepsin and the degree of dilution (Manuelian et al., 2017).

Table 1. Chemical composition of Mediterranean buffalo bulk milk samples

\begin{tabular}{lccccc}
\hline Trait & $\mathrm{n}$ & Mean & SD & Minimum & Maximum \\
\hline Milk composition, \% & & & & & \\
Fat & 1,143 & 7.94 & 0.63 & 5.93 & 9.92 \\
Protein & 1,138 & 4.52 & 0.23 & 3.78 & 5.20 \\
Casein & 1,144 & 3.76 & 0.23 & 3.04 & 4.42 \\
Lactose & 1,154 & 4.80 & 0.17 & 3.89 & 6.10 \\
Citric acid & 1,261 & 0.13 & 0.02 & 0.08 & 0.20 \\
Log $_{10}$ SCC & 1,255 & 5.18 & 0.25 & 4.43 & 7.91 \\
pH & 1,141 & 6.77 & 0.11 & 6.43 & 7.08 \\
\hline
\end{tabular}




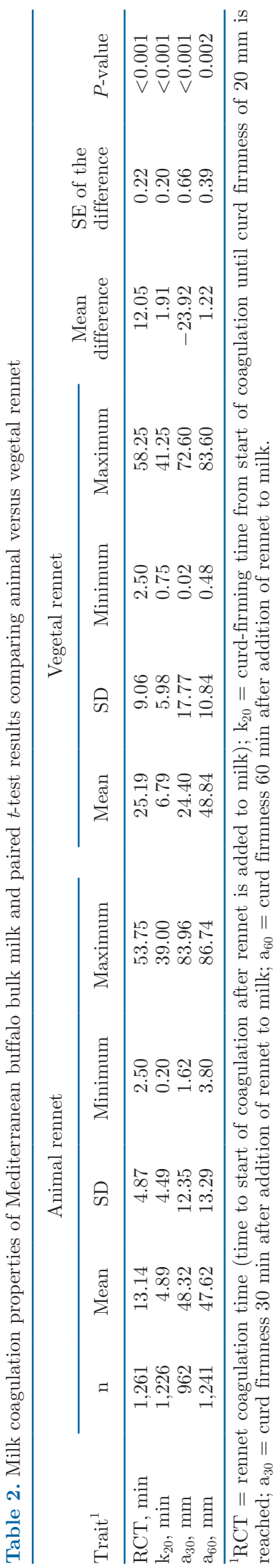

\section{Milk Coagulation Properties Using Vegetal Rennet}

When using the commercial vegetal rennet, 39 out of 1,302 milk samples $(3.0 \%)$ did not start to coagulate within the 60 min of analysis. Moreover, 73 out of 1,302 samples $(5.6 \%)$ did not achieve 20-mm curd firmness within the $60 \mathrm{~min}$ of analysis. Table 2 displays the descriptive statistics of MCP for bulk buffalo milk using animal and vegetal rennets. Considering the results obtained with vegetal rennet, the $\mathrm{CV}$ were $36 \%$ for $\mathrm{RCT}$, $88 \%$ for $\mathrm{k}_{20}, 73 \%$ for $\mathrm{a}_{30}$, and $22 \%$ for $\mathrm{a}_{60}$.

Most studies of vegetal rennet have been performed using cow or sheep milk and rennets including species of the genus Cynara L. (Roseiro et al., 2003; Ben Amira et al., 2017a; Troch et al., 2017). Unlike that of animal rennet, coagulation activity of vegetal rennet is highly variable due to differences in the botanical composition of the rennet, the purity of the extract, the state of maturity of the plant, the part of the plant used (e.g., flowers vs. leaves), and the conditions of collection, season, and storage (Heimgarter et al., 1990; Ben Amira et al., 2017a; Troch et al., 2017). Vegetal rennets based on Cynara cardunculus are the most used in cheese production, due to the presence of the aspartic proteinases cardosin A and B (which are analogous to chymosin and pepsin, respectively, in terms of activity and specificity) that have the ability to hydrolyze the Phe105-Met106 bond of k-casein (Veríssimo et al., 1995; Ben Amira et al., 2017a), which is necessary for rennet milk clotting.

Moreover, different techniques to assess MCP using vegetal rennet have been used and have provided different MCP traits than the ones determined in the present study. For example, Esteves et al. (2002; 2003a,b) used a dynamic rheometer, and Ben Amira et al. (2017b) used a rheometer with an oscillatory mode to evaluate the rennetability of vegetal rennet in cow milk. These 2 rheometers allow continuous measurement of the viscoelastic properties during the whole coagulation process by applying a strain (or stress) on the gelling sample. Thus, the parameters determined are the storage modulus $\left(\mathbf{G}^{\prime}\right.$, expressed in $\left.\mathrm{Pa}\right)$, which is the measure of gel strength; the gelation time (GT, expressed in min), which is the time needed for $\mathrm{G}^{\prime}$ to exceed a predefined pressure threshold; and the loss modulus $\left(\mathbf{G}^{\prime \prime}\right.$, expressed in $\left.\mathrm{Pa}\right)$. When comparing the Formagraph with a rheometry method, an agreement has been observed between GT and RCT values (Ketto et al., 2015). Comparing our results with studies that used different plant extracts of $C$. cardunculus and $C y$ nara humilis in cow milk, we obtained greater RCT than the GT reported by Esteves et al. (2002; 2003a,b) and Ben Amira et al. (2017b). 


\section{Vegetal Versus Animal Rennet on Milk Coagulation Properties}

A greater $\mathrm{CV}$ for $\mathrm{a}_{30}$ was obtained with vegetal than with animal rennet. On the other hand, similar variability between animal and vegetal rennet has been observed for RCT, $\mathrm{k}_{20}$, and $\mathrm{a}_{60}$. On average, when using plant rennet, milk started coagulating 12 min later than with animal rennet $(P<0.001$; Table 2 ; Figure 1$)$. Ben Amira et al. (2017b) have also reported a longer time for C. cardunculus than chymosin rennet to start coagulating reconstituted skim cow milk (determined at $\mathrm{G}^{\prime}=1 \mathrm{~Pa}$; difference of $7 \mathrm{~min}$ in $\mathrm{GT}$ ) at $30^{\circ} \mathrm{C}$ using a dose concentration of the enzyme of $0.5 \mathrm{mg} / 10 \mathrm{~mL}$. However, in the same study, the authors indicated a longer time for chymosin than $C$. cardunculus in raw skim cow milk (difference of $4 \mathrm{~min}$ in GT). Esteves et al. (2003a), at $35^{\circ} \mathrm{C}$ of gelation temperature, reported a longer time for chymosin than for $C$. cardunculus or C. humilis to start coagulating reconstituted cow skim milk (determined at $\mathrm{G}^{\prime}=0.5 \mathrm{~Pa}$; almost $5 \mathrm{~min}$ of difference of GT).

Nevertheless, the same authors did not observe differences between the coagulation enzyme used when the assay was conducted at $32^{\circ} \mathrm{C}$ (Esteves et al., 2003a,b), even at different $\mathrm{pH}$ conditions ( $\mathrm{pH}$ from 6.0 to 6.7; Esteves et al., 2003b). Moreover, in the present study, almost all the samples $(99.52 \% ; 1,255$ out of 1,261$)$ started coagulating before $30 \mathrm{~min}$ when using animal rennet, whereas only $70.42 \%$ (888 out of 1,261) of the samples started to coagulate within the first $30 \mathrm{~min}$ when using vegetal rennet (Figure 2). Manuelian et al. (2017) have reported a lower percentage of samples that coagulated within the first $30 \mathrm{~min}$ of the analysis (87\%) using the same animal rennet in individual buffalo milk samples.

The $\mathrm{k}_{20}$ was reached 1.9 min earlier using animal compared with vegetal rennet (Table 2) due to a faster velocity of aggregation from $\mathrm{RCT}$ to $\mathrm{k}_{20}$, which was 4.09 and $2.94 \mathrm{~mm} / \mathrm{min}$ for animal and vegetal rennet, respectively (Figure 1). Moreover, considering the beginning of the assay, when the enzyme was added to the milk sample, the time difference between both rennets to achieve $20-\mathrm{mm}$ coagulum was even greater (12 $\mathrm{min}$ faster with the animal rennet; Figure 1). Because of the delay in starting the aggregation process when using vegetal rennet, $\mathrm{a}_{30}$ was almost twice as firm in animal than in vegetal rennet (Table 2; Figure 1). However, $\mathrm{a}_{60}$ differed by only $1.21 \mathrm{~mm}$ between both rennets (Table 2; Figure 1). Measurements between 30 and 60 min after enzyme addition would be interesting, to better determine the time at which the enzymes produce the same coagulum thickness. In addition, considering the prolonged coagulation time of the vegetal rennet used

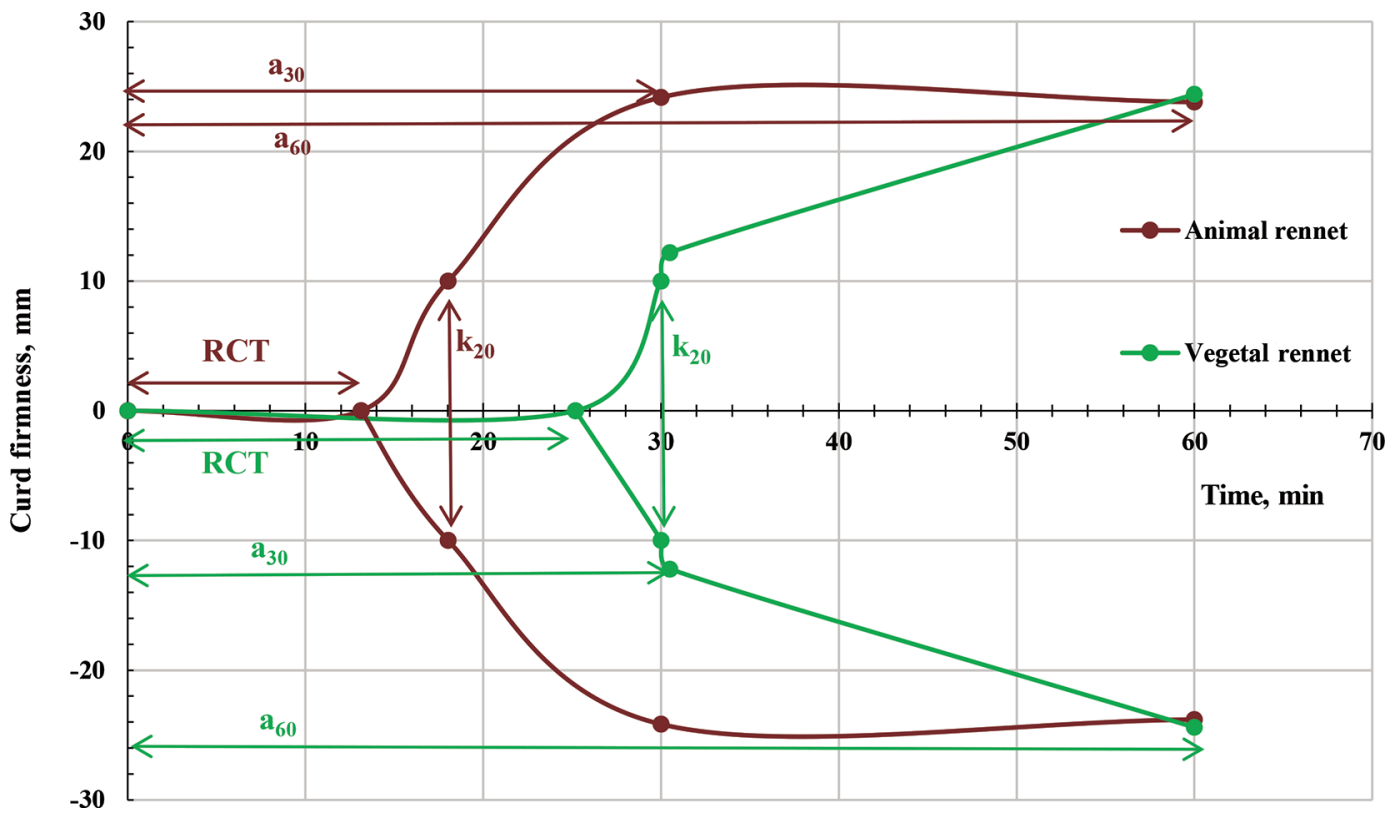

Figure 1. Diagram of coagulation and curd firmness of Mediterranean buffalo bulk milk samples as a function of time and rennet used (animal or vegetal). The same bulk milk sample was tested using animal and vegetal rennet. Dots represent the average values for RCT (rennet coagulation time, time to start of coagulation after addition of rennet to milk; $\mathrm{n}=1,261$ ); $\mathrm{k}_{20}$ (curd-firming time from start of coagulation until curd firmness of $20 \mathrm{~mm}$ is achieved; $\mathrm{n}=1,226$ ); $\mathrm{a}_{30}$ (curd firmness $30 \mathrm{~min}$ after addition of rennet to milk; $\mathrm{n}=962$ ); and $\mathrm{a}_{60}$ (curd firmness 60 min after addition of rennet to milk; $\mathrm{n}=1,242)$. 


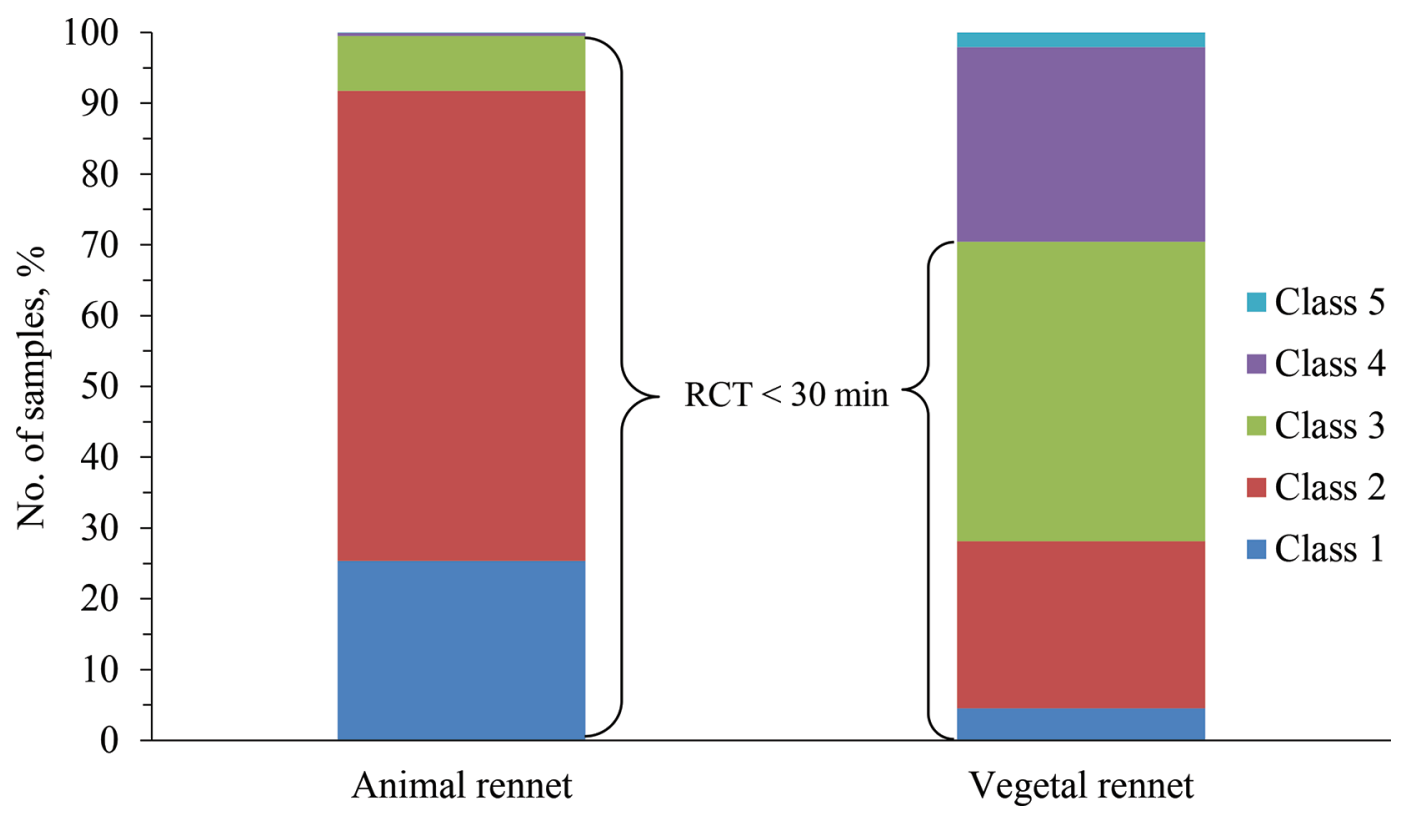

Figure 2. Proportion of Mediterranean buffalo bulk milk samples classified according to their rennet coagulation time (RCT, time to start of coagulation after addition of rennet to milk) using animal or vegetal rennet. Class 1: RCT $<10$ min; class 2: 10 min $\leq$ RCT $<20$ min; class 3: $20 \mathrm{~min} \leq \mathrm{RCT}<30 \mathrm{~min} ;$ class $4: 30 \mathrm{~min} \leq \mathrm{RCT}<45 \mathrm{~min}$; and class $5: 45 \mathrm{~min} \leq \mathrm{RCT}<60 \mathrm{~min}$.

and the subsequent whey drainage step, the quantity of vegetal rennet added might be adjusted to better fit the coagulation behavior. Nevertheless, to produce Mozzarella di latte di Bufala, after forming and cutting the curd, fermentation continues under the whey for about $3 \mathrm{~h}$, and then the cheese is put on steel racks to drain for a few more hours. Thus, a delay of about 20 to 30 min when using the vegetal rennet could be considered marginal in proportion to the complete process (6 to $7 \mathrm{~h})$.

The slight difference observed for $\mathrm{a}_{60}$ between animal and vegetal rennet in the present study was consistent with previous studies that assessed $\mathrm{G}^{\prime}$ using chymosin or vegetal extracts from the genus Cynara L. (Esteves et al., 2003a; Ben Amira et al., 2017b). The $\mathrm{G}^{\prime}$ performed similarly to curd firmness determined with Formagraph: at higher coagulum thickness, greater pressure must be applied (Ketto et al., 2015). Ben Amira et al. (2017b) reported a similar $\mathrm{G}^{\prime}$ between chymosin and vegetal extracts at the end of the assay (60 min after addition of the coagulant) in raw skimmed cow milk at $30^{\circ} \mathrm{C}$; similar results were reported by Esteves et al. (2003a) at the end of the assay ( $3 \mathrm{~h}$ after addition of the coagulant) when comparing chymosin and C. cardunculus rennets at $32^{\circ} \mathrm{C}$ and $35^{\circ} \mathrm{C}$ of gelation temperature in reconstituted cow skim milk. On the other hand, Esteves et al. (2003b) reported a greater $\mathrm{G}^{\prime}$ at the end of the assay (6 $\mathrm{h}$ after the addition of the coagulant) when using chymosin than when using plant extracts from the genus Cynara L.; however, that difference was lower at $\mathrm{pH} 6.7$, being $12 \mathrm{~Pa}$ instead of $20 \mathrm{~Pa}$.

\section{CONCLUSIONS}

The present study compared the clotting activity of commercial animal and vegetable rennets $(C$. cardunculus) on buffalo bulk milk. Milk samples with vegetal rennet took more time to begin coagulation than when using animal rennet. However, at the end of the assay (60 min), both rennets presented similar coagulum thickness, suggesting similar viscoelastic properties of the final product. Therefore, from an analytical point of view, vegetal rennet could be used to produce Mozzarella and other cheeses from buffalo milk, allowing more time for the enzyme to actuate. Further studies are needed to assess the sensory properties and texture characteristics of the product, to ensure consumer acceptability. In addition, the cost effectiveness of the use of vegetal rennet by the dairy industry should be evaluated, as it might be necessary to use greater amounts of vegetal rennet to achieve $a_{30}$ comparable to that of cheeses made with animal rennet.

\section{ACKNOWLEDGMENTS}

This paper is based on the research project CUP: G83118000070001, funded by the Italian Ministry of 
Health (Rome, Italy). The authors have not stated any conflicts of interest.

\section{REFERENCES}

Addeo, F., V. Alloisio, L. Chianese, and V. Alloisio. 2007. Tradition and innovation in the water buffalo dairy products. Ital. J. Anim. Sci. 6(Suppl. 2):51-57. https://doi.org/10.4081/ijas.2007.s2.51.

Ali, A. K. A., and G. E. Shook. 1980. An optimum transformation for somatic cells concentration in milk. J. Dairy Sci. 63:487-490. https://doi.org/10.3168/jds.S0022-0302(80)82959-6.

A.N.A.S.B. (National Association of Buffalo Breeders). 2019. National data statistics. Accessed Apr. 10, 2019. http://www.anasb.it/home .htm.

Ariota, B., G. Campanile, A. Potena, R. Napolano, B. Gasparrini, G. L. Neglia1, and R. Di Palo. 2007. Ca and P in buffalo milk: Curd yield and milk clotting parameters. Ital. J. Anim. Sci. 6(Suppl. 1):497-499. https://doi.org/10.4081/ijas.2007.1s.497.

Bartocci, S., C. Tripaldi, and S. Terramoccia. 2002. Characteristics of foodstuffs and diets, and the quanti-qualitative milk parameters of Mediterranean buffaloes bred in Italy using the intensive system: An estimate of the nutritional requirements of buffalo herds lactating or dry. Livest. Prod. Sci. 77:45-58. https://doi.org/10.1016/ S0301-6226(02)00022-2.

Bathmanathan, R., Y. A. C. Yahya, M. M. Yusoff, and J. Vejayan. 2019. Utilizing coagulant plants in the development of functional dairy foods and beverages: A mini review. J. Biol. Sci. 19:259-271. https://doi.org/10.3923/jbs.2019.259.271.

Ben Amira, A., S. Besbes, H. Attia, and C. Blecker. 2017a. Milk-clotting properties of plant rennets and their enzymatic, rheological, and sensory role in cheese making: A review. Int. J. Food Prop. 20(Suppl. 1):S76-S93. https://doi.org/10.1080/10942912.2017 .1289959 .

Ben Amira, A., A. Mokni, H. Yaich, M. Chaabouni, S. Besbes, C. Blecker, and H. Attia. 2017b. Technological properties of milk gels produced by chymosin and wild cardoon rennet optimized by response surface methodology. Food Chem. 237:150-158. https://doi .org/10.1016/j.foodchem.2017.05.105.

Borghese, A. 2005. Buffalo milk and cheese industry. Pages 185-196 in Buffalo Production and Research. Food and Agriculture Organization of the United Nations, Rome, Italy.

Borghese, A. 2013. Buffalo livestock and products in Europe. Buffalo Bulletin 32 (Special Issue 1):50-74. Accessed May 13, 2019. http:/ /ibic.lib.ku.ac.th/e-bulletin/IBBUSI201301004.pdf.

Cecchinato, A., M. Penasa, C. Cipolat Gotet, M. De Marchi, and G. Bittante. 2012. Short communication: Factors affecting coagulation properties of Mediterranean buffalo milk. J. Dairy Sci. 95:1709-1713. https://doi.org/10.3168/jds.2011-4694 https://doi .org/sid10.3168/jds.2011-4694.

CLAL. 2019a. Farm-gate milk prices, Italy (Lombardia). Accessed Feb. 25, 2019. https://www.clal.it/en/index.php?section=latte _lombardia.

CLALL. 2019b. Produzioni di Mozzarella di Bufala Campana DOP, Italia. Accessed Feb. 25, 2019. https://www.clal.it/?section= mozzarella_bufala_campana.

Di Francia, A., F. Masucci, M. T. Maresca di Serracapriola, F. Gioffré, and V. Proto. 2003. Nutritional factors influencing milk urea in buffaloes. Ital. J. Anim. Sci. 2:225-227. https://doi.org/10.4081/ ijas.2003.11675968.

Esteves, C. L. C., J. A. Lucey, D. B. Hyslop, and E. M. V. Pires. 2003a. Effect of gelation temperature on the properties of skim milk gels made from plant coagulants and chymosin. Int. Dairy J. 13:877-885. https://doi.org/10.1016/S0958-6946(03)00114-6.

Esteves, C. L. C., J. A. Lucey, and E. M. V. Pires. 2002. Rheological properties of milk gels made with coagulants of plant origin and chymosin. Int. Dairy J. 12:427-434. https://doi.org/10.1016/ S0958-6946(01)00170-4.

Esteves, C. L. C., J. A. Lucey, T. Wang, and E. M. V. Pires. 2003b. Effect of $\mathrm{pH}$ on the gelation properties of skim milk gels made from plant coagulants and chymosin. J. Dairy Sci. 86: 2558-2567. https: //doi.org/10.3168/jds.S0022-0302(03)73850-8.

FAOSTAT. 2019. Livestock Primary. Accessed Feb. 25, 2019. http:// www.fao.org/faostat/en/\#data/QL.

Guo, M. 2010. Improving buffalo milk. Pages 402-416 in Improving the Safety and Quality of Milk: Improving Quality in Milk. Vol. 2. M. W. Griffiths, ed. Woodhead Publishing, Cambridge, England. https://doi.org/10.1533/9781845699437.3.402.

Heimgartner, U., M. Pietrzak, R. Geertsen, P. Brodelius, A. C. Da Silva Figueiredo, and M. S. S. Pais. 1990. Purification and partial characterization of milk clotting proteases from flowers of Cynara cardunculus. Phytochemistry 29:1405-1410. https://doi.org/10 $.1016 / 0031-9422(90) 80090-4$.

Jacob, M., D. Jaros, and H. Rohm. 2011. Recent advances in milk clotting enzymes. Int. J. Dairy Technol. 64:14-33. https://doi.org/10 .1111/j.1471-0307.2010.00633.x.

Ketto, I. A., R. B. Schüller, E.-O. Rukke, A. G. Johansen, and S. B. Skeie. 2015. Comparison between Formagraph and low-amplitude oscillation rheometry in monitoring coagulation properties of acid induced gels in bovine milk. Ann T. Nord. Rheol Soc. 23:13-20.

Liburdi, K., C. Boselli, G. Giangolini, S. Amatiste, and M. Esti. 2019. An evaluation of the clotting properties of three plant rennets in the milks of different animal species. Foods 8:600. https://doi.org/ 10.3390 /foods 8120600 .

Liotta, L., V. Chiofalo, V. Lo Presti, A. Vassallo, G. Dalfino, and A. Zumbo. 2015. The influence of two different breeding systems on quality and clotting properties of milk from dairy buffaloes reared in Sicily (Italy). Ital. J. Anim. Sci. 14:3669. https://doi.org/10 .4081/ijas.2015.3669.

Manuelian, C. L., G. Visentin, C. Boselli, G. Giangolini, M. Cassandro, and M. De Marchi. 2017. Short communication: Prediction of milk coagulation and acidity traits in Mediterranean buffalo milk using Fourier-transform mid-infrared spectroscopy. J. Dairy Sci. 100:7083-7087. https://doi.org/10.3168/jds.2017-12707.

McMahon, D. J., and R. J. Brown. 1982. Evaluation of Formagraph for comparing rennet solutions. J. Dairy Sci. 65:1639-1642. https: //doi.org/10.3168/jds.S0022-0302(82)82390-4.

Ministero delle Politiche Agricole e Forestali. 2003. Disciplinare di produzione della Denominazione di Origine Protetta "Mozzarella di Bufala Campana." Allegato al D.M. 18.09.2003 (G.U. n. 258 del 6.11.2003).

Pasquini, M., A. Osimani, S. Tavoletti, I. Moreno, F. Clementi, and M. F. Trombetta. 2018. Trends in the quality and hygiene parameters of bulk Italian Mediterranean buffalo (Bubalus bubalis) milk: A three year study. Anim. Sci. J. 89:176-185. https://doi.org/10 $.1111 /$ asj. 12916.

Roseiro, L. B., M. Barbosa, J. M. Ames, and R. A. Wilbey. 2003. Cheesemaking with vegetable coagulants-The use of Cynara L. for the production of ovine milk cheeses. Int. J. Dairy Technol. 56:76-85, https://doi.org/10.1046/j.1471-0307.2003.00080.x.

Troch, T., É. Lefébure, V. Baeten, F. Colinet, N. Gengler, and M. Sindic. 2017. Cow milk coagulation: Process description, variation factors and evaluation methodologies. A review. Biotechnol. Agron. Soc. Environ. 21:276-287. http://hdl.handle.net/2268/ 213090.

Veríssimo, P., C. L. C. Esteves, C. Faro, and E. M. V. Pires. 1995. The vegetable rennet of Cynara cardunculus L. contains two proteinases with chymosin and pepsin-like specificities. Biotechnol. Lett. 17:621-626. https://doi.org/10.1007/BF00129389.

\section{ORCIDS}

C. L. Manuelian () https://orcid.org/0000-0002-0090-0362

C. Boselli $\odot$ https://orcid.org/0000-0002-3990-1063

V. Vigolo $\odot$ https://orcid.org/0000-0001-6413-3257

G. Giangolini $\odot$ https://orcid.org/0000-0002-7820-0593

M. De Marchi ๑ https://orcid.org/0000-0001-7814-2525 